\title{
The usefulness of laparoscopic adrenalectomy in the treatment of adrenal neoplasms a single-centre experience
}

\author{
Przydatność adrenalektomii laparoskopowej w leczeniu nowotworów nadnerczy \\ w doświadczeniu jednoośrodkowym
}

\author{
Ryszard Pogorzelski', Sadegh Toutounchi ${ }^{1}$, Ewa Krajewska ${ }^{1}$, Patryk Fiszer ${ }^{1}$, Agata Kącka ${ }^{2}$, \\ Mariusz Piotrowski ${ }^{2}$, Małgorzata Szostek ${ }^{1}$, Tomasz Wołoszko ${ }^{1}$, Krzysztof Celejewski ${ }^{1}$, \\ Urszula Ambroziak ${ }^{3}$, Tomasz Bednarczuk ${ }^{3}$, Zbigniew Gałązka ${ }^{1}$
}

${ }^{1}$ Department of General and Endocrine Surgery, Medical University of Warsaw, Poland

${ }^{2} 2 n d$ Department of Anaesthesia and Intensive Therapy, Medical University of Warsaw, Poland

${ }^{3}$ Department of Internal Medicine and Endocrinology, Medical University of Warsaw, Poland

\begin{abstract}
Introduction: Adrenal neoplasms comprise about $10 \%$ of all tumours affecting this organ and constitute a significant, at first diagnostic and subsequently therapeutic, problem, especially since a relatively high proportion of neoplastic lesions are asymptomatic. The number of diagnosed metastases to adrenal glands is increasing. Surgical treatment involves both open surgery as well as laparoscopy.

Material and methods: There were 245 adrenalectomies performed at our centre due to various indications over the past four years. In 27 $(11.5 \%)$ cases neoplasms were diagnosed in the final histopahtological examination. In $11(40.7 \%)$ cases primary adrenal cortex tumours were diagnosed, metastases from other solid organ tumours were identified in another $12(44.4 \%)$ patients, and rarer neoplasms were diagnosed in the remaning $4(14.8 \%)$ subjects. Cases of malignant pheochromocytoma were not included in this report.

Results: Laparoscopic adrenalectomy was performed in 23 (85.2\%) subjects, while the ramaining $4(12.9 \%)$ patients were subject to open adrenalectomy (conversion to open procedure in one case). There were no deaths or significant complications in the perioperative period. Comparing mean duration of open (140 minutes) and laparoscopic (190 minutes) procedures yielded a statistically significant difference $(p=0.02)$. There was no statistically significant difference found in the duration of operation with regard to laparoscopic adrenalectomies of tumours less than $50 \mathrm{~mm}$ and over $55 \mathrm{~mm}$ in diameter $(\mathrm{p}=0.16)$.

Conclusions: Laparoscopic adrenalectomy is a safe and effective method of treatment of adrenal tumours. Its oncological completeness is comparable (to open surgery) when performed by experienced surgical teams. Laparoscopy is the reason for the smooth postoperative course observed in most patients. (Endokrynol Pol 2017; 68 (4): 407-410)
\end{abstract}

Key words: adrenal cancer, adrenalectomy, laparoscopic adrenalectomy, adrenal gland metastases

\section{Streszczenie}

Wstęp: Nowotwory nadnerczy występują w około 10\% wszystkich guzów tego narządu i stanowią bardzo istotny problem początkowo diagnostyczny, a następnie leczniczy. Tym bardziej, że dość duży odsetek zmian nowotworowych nadnerczy przebiega bezobjawowo. Stwierdza się też coraz więcej zmian przerzutowych do nadnerczy. Leczenie jest chirurgiczne zarówno metodami chirurgii otwartej, jak i laparoskopowej.

Materiał i metody: W okresie ostatnich 4 lat w tutejszym ośrodku wykonano 245 adrenalektomii z różnych wskazań. U 27 (11,5\%) w ostatecznym badaniu histopatologicznym rozpoznano nowotwory. U 11 pacjentów (40,7\%) rozpoznano pierwotne raki kory, u kolejnych 12 chorych $(44,4 \%)$ przerzuty nowotworów narządowych, u pozostałych $4(14,8 \%)$ inne rzadsze nowotwory. W opracowaniu nie uwzględniono złośliwych postaci pheochromocytoma.

Wyniki: U 23 (85,2\%) wykonano adrenalektomię laparoskopową, u pozostałych 4 (12,9\%) adrenalektomię otwartą (w jednym przypadku była to konwersja). W okresie okołooperacyjnym nie było zgonów ani istotnych powikłań. Ten przedłużony pobyt związany był z przekazaniem chorych do dalszego leczenia skojarzonego. Porównano średnie czasy trwania operacji otwartych (140 min) i laparoskopowych (190 min) uzyskując statystyczną znamienność $(\mathrm{p}=0,02)$. Nie uzyskano znamienności statystycznej w czasie trwania adrenalektomii laparoskopowych dla guzów o średnicy do $50 \mathrm{~mm}$ i powyżej $55 \mathrm{~mm}(\mathrm{p}=0,16)$.

Wnioski: Adrenalektomia laparoskopowa jest bezpieczną i skuteczną metodą leczenia nowotworów nadnerczy. Jest też porównywalna $\mathrm{w}$ doszczętności onkologicznej gdy jest wykonywana przez doświadczone zespoły operacyjne. Laparoskopia u większości operowanych ma łagodny przebieg pooperacyjny. (Endokrynol Pol 2017; 68 (4): 407-410)

Słowa kluczowe: rak nadnercza, adrenalektomia, adrenalektomia laparoskopowa przerzuty do nadnerczy 


\section{Introduction}

Frequency of appearance of adrenocortical carcinoma (ACC) ranges from 1-10\% in patients with adrenal tumours [1]. In the total population (ACC) estimated as 0.5 to 2 cases per one million.

Metastatic tumours pose a great diagnostic and therapeutic challenge. In patients suffering from carcinoma of different organs, metastases into adrenal glands are found in 10 to $25 \%$ of cases, with a greater percentage in postmortem examination $[2,3]$. Ninety per cent of patients with adrenal neoplasms, both primary and secondary, are asymptomatic. Clinical observation shows that tumours larger than $60 \mathrm{~mm}$ in diameter are more often malignant [4,5]. Adrenal, incidentally found tumours are diagnosed in $0.35-4.4 \%$ of the patients during CT scan of the abdomen or in 0.4 to $1.9 \%$ of the patients during ultrasound examination [6].

Both groups may require surgical treatment, i.e. open or laparoscopic adrenalectomy. The open method is used for the treatment of large tumours with infiltration of neighbouring tissues.

Laparoscopic adrenalectomy is now widely used for operative treatment of adrenal gland tumours because it is a less invasive technique than open surgery. In literature there are many publications comparing both methods and their complications, radical oncological therapy, duration of the operation, blood loss, and hospitalisation time. In most cases, the laparoscopic method seems to be better than the open procedure $[7,8]$. The surgical technique must be adjusted to the patients' needs.

The authors present a single-centre study of patients treated with laparoscopy for neoplasm of the adrenal glands.

\section{Material and methods}

From the beginning of 2011 until the end of June 2014, 245 patients were operated in our centre due to adrenal tumours. In that group, in 27 cases $(11.5 \%)$ primary and metastatic malignancies were found. This group comprised 17 women and 10 men aged from 38 to 85 years (mean age 60 years). In our study we excluded pheochromocytoma.

The results of comparable parameters were statistically assessed by Mann-Whitney U test. The time of laparoscopic and open adrenalectomy procedure was compared according to tumour size. All adrenalectomies were performed by the same team. The laparoscopic method was done using a transperitoneal lateral approach. Four trocars were used for this operation.
Table I. Type of neoplasms in adrenal gland according to histopathological examination

Tabela I. Rodzaje nowotworów nadnerczy w rozpoznaniu histopatologicznym

\begin{tabular}{lll}
\hline Type of neoplasm & Number of patients & $\%$ \\
\hline ACC & 11 & 40.8 \\
\hline Metastases & 12 & 44.4 \\
-Lung & 5 & \\
-Bladder & 3 & \\
-Kidney & 2 & \\
-Unknown & 2 & 7.4 \\
\hline Lymphoma* & 2 & 7.4 \\
\hline Other** & 2 & 100 \\
\hline Total & 27 & \\
\hline
\end{tabular}

* Diffused lymphoma, big B cell (both cases)

** Malignant epithelioid haemangiothelioma in one case and histiocytic sarcoma in other

\section{Results}

In 12 patients a tumour was found in the right adrenal gland, and in remaining 15 it was located on the left side. In 26 cases (96.3\%) there were non-secreting tumours, and in one case (3.7\%) there was coexistence of ACC with Cushing's syndrome. In 14 patients (51.9\%) past history of malignancy and oncological operations of different organs were found (mainly lungs, bladder, kidney, and lymphomas). In 13 patients $(48.1 \%)$ there were no clear data for diagnosis of neoplasm in clinical, laboratory, or radiological examination (Table I).

In 13 patients (48.1\%) there were no clear data for diagnosis of neoplasm in clinical, laboratory, or radiological examination. In 14 patients (51.9\%) past history of malignancy and oncological operations of different organs were found (mainly lungs, bladder, kidney, and lymphomas) (Table I).

Laparoscopic adrenalectomy was performed in $23(85.2 \%)$ of the patients. In four patients $(12.9 \%)$ an open method was used (open surgery was performed in cases of stage ENSAT III; conversion from laparoscopic method was performed in one case, due to technical and anatomical problems). The diameter of the tumours ranged from 4 to $10 \mathrm{~cm}$. Duration of open adrenalectomy was from 90 to 180 minutes (mean 140 minutes). Laparoscopic operation was completed in from 135 to 240 minutes (mean 190 minutes). The time of open operation was significantly shorter than the time of the laparoscopic operation $(p=0.02)$. Patients qualified for laparoscopic adrenalectomy were divided into two groups according to size of the malformation. In 10 patients (45.5\%) tumours up to $50 \mathrm{~mm}$ were diagnosed, and in 12 patients $(54.5 \%)$ the size of the 
tumour was greater than $55 \mathrm{~mm}$. In first group the time of the operation was from 130 to 240 minutes (mean 160 minutes). In the second group the time of the operation was from 135 to 240 minutes (mean 190 minutes). In both groups there was no significant difference in the duration of the operation $(p=0.16)$. The time of hospital stay was from 5 to 22 days (mean 9.8 days). There was no correlation between the kind of operation and time of hospitalisation. Longer hospital stay was due to basic illness, qualification for combined therapy, or diagnostic procedures necessary for combined therapy. In the perioperative period there were no serious complications (tumour rupture, pulmonary embolism, serious bleeding, stroke) or deaths observed. Moreover, there were no minor complications (wound haematoma, wound infection). In all cases, oncological radicality and the final diagnosis was confirmed by histopathological examination. All patients were transferred to the department of oncology for continuation of their therapy. All patients with ACC were qualified to mitotane treatment. No mortality in the perioperative period or during the hospital stay was observed. In this study there was no assessment of long-term results (it may be the subject of the next study)

\section{Discussion}

All patients in this study were diagnosed in general, endocrinological, or oncological centres, where laboratory tests and imaging studies such as CT scan, MRI, ultrasound, or PET scan were done. All these tests preceding surgery gave no answer about the diagnosis in the preoperative period in the majority of patients. The data confirming diagnosis of neoplasm were collected during patient examination, when information about history of cancer was obtained. It was the same in all patients with metastases. In our centre needle biopsy was not performed because of the risk of complications (bleedings, local neoplasm infiltrations) (Fig. 1, 2).

Together with development of the technique and skills in laparoscopic adrenalectomy, it is possible to widen indications and decrease the number of contraindications. Clinical experience shows that the presence of a malignancy with diameter greater than $10 \mathrm{~cm}$ qualifies for laparoscopy, but there must be no infiltration of the tumour into neighbouring tissues [7]. In the case of larger, benign tumours, not hormonally active, laparoscopic adrenalectomy in technically possible. Many authors state that laparoscopic treatment should be individualised according to the size of the tumour and development of the disease itself. Many authors prefer the laparoscopic technique $[2,9,10]$. In the case of laparoscopic and open excision of metastatic

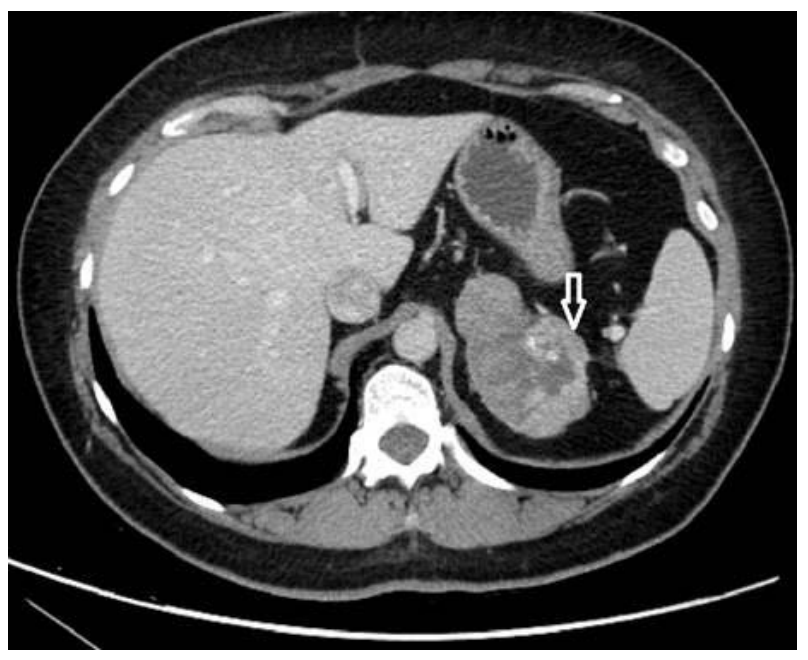

Figure 1. Adrenal neoplasm - CT scan

Rycina 1. Nowotwór nadnerczy - tomografia komputerowa

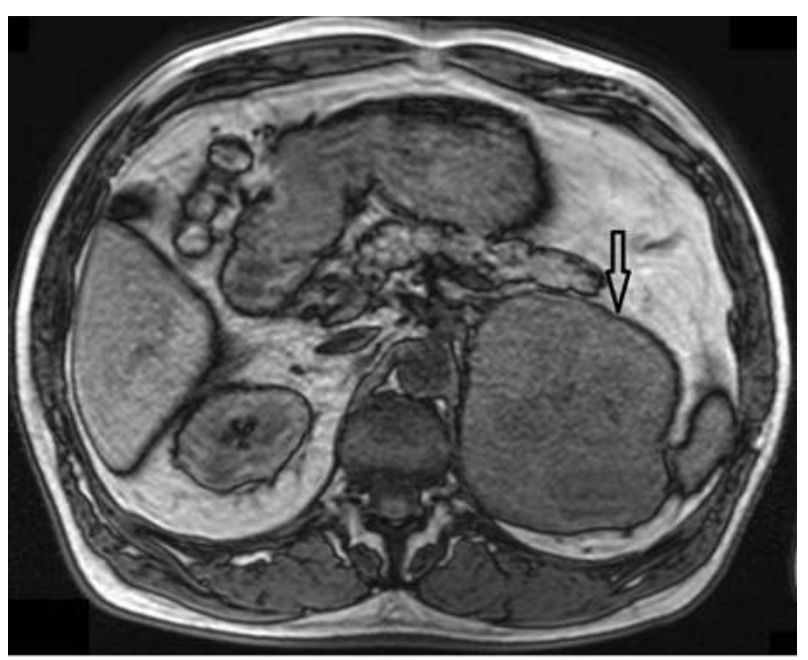

Figure 2. Adrenal neoplasm - MR scan

Rycina 2. Nowotwór nadnerczy - rezonans magnetyczny

tumours from adrenal glands, there is no difference found in the margin surrounding the excised tumour, as well as in recurrence of the tumour at the site of the operation, and mean survival time in the perioperative period [3]. The authors carried out laparoscopic adrenalectomy in 23 out of 27 cases (ENSAT stage I and II). In one case conversion to the open method was necessary because of difficult anatomical conditions at the operation field (Fig. 3).

According to different authors, earlier abdominal operations are not a contraindication for laparoscopic adrenalectomy done using the peritoneal approach. They may extend the time of operation because removal of adhesions is necessary for a good view [11, 12]. The authors state that adhesions are not found in every patient, so the operation field may be assessed after 


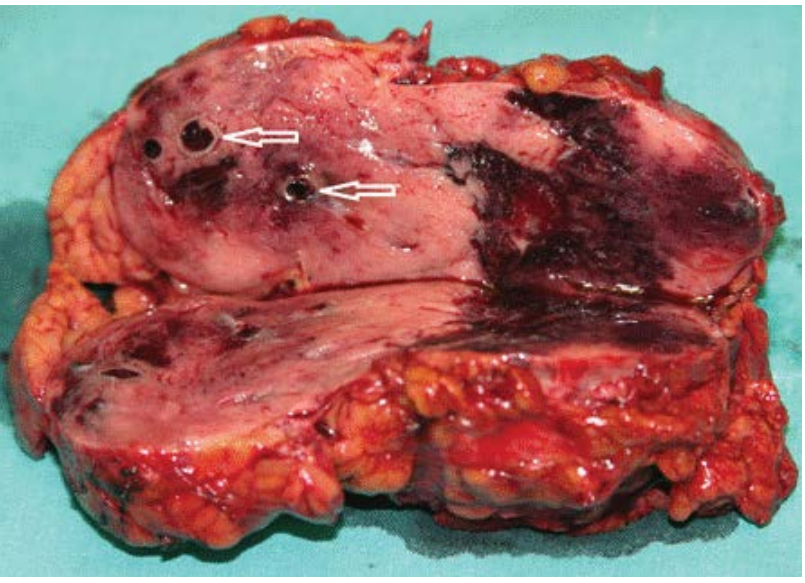

Figure 3. Specimen of adrenal neoplasm - in cross-section main body of the tumor with pathological vessels

Rycina 3. Objawy nowotworu nadnerczy - w głównym przekroju poprzecznym guza z patologicznymi naczyniami

introduction of the camera into the peritoneal cavity. The rear retroperitoneal approach is the solution to this problem, especially in old patients or those in a severe state, with small tumours in adrenal glands. The number of non-severe complications of laparoscopic adrenalectomy, reaching $10 \%$, is acceptable. Conversions to the open method are done in $5 \%$ of all cases [13-15]. Similar results were found in the presented study as well as in patients with malignancies and in patients with benign tumours not hormonally active. One must remember that patients with hormone-secreting tumours need interdisciplinary preparation for the operation, which is important for stability in the perioperative period and the number of complications [16, 17].

Among metastatic tumours, metastases of lung carcinoma, large bowel, and kidney are most frequent. They may present synchronically and metachronically, and it was isolated metastasis. In the study group, 12 metastatic tumours were found, and in five cases these were lung carcinomas. They were diagnosed a few or many months after excision of the primary tumour. From other studies it is well known that metastasectomy from adrenal glands together with combined treatment prolong the life of the patients [18, 19].

\section{Conclusions}

1. Laparoscopic adrenalectomy is an effective, safe, and well tolerated method of treatment of neoplasms located in adrenal glands.

2. Radical oncological surgery with laparoscopic adrenalectomy is comparable to the classical method.
This method of treatment is possible in centres where proper qualification of the patients is performed and care is taken by an experienced, well trained team of surgeons and anaesthetists.

\section{References}

1. Assié G, Letouzé E, Fassnacht M, et al. Integrated genomic characterization of adrenocortical carcinoma. Nat Genet. 2014; 46(6): 607-612, doi: 10.1038/ng.2953, indexed in Pubmed: 24747642.

2. Terzolo M, Daffara F, Ardito A, et al. Management of adrenal cancer: a 2013 update. J Endocrinol Invest. 2014; 37(3): 207-217, doi: 10.1007/ s40618-013-0049-2, indexed in Pubmed: 24458831.

3. Bradley CT, Strong VE. Surgical management of adrenal metastases. J Surg Oncol. 2014; 109(1): 31-35, doi: 10.1002/jso.23461, indexed in Pubmed: 24338382

4. Mege D, Taieb D, Lowery A, et al. Contemporary review of large adrenal tumors in a tertiary referral center. Anticancer Res. 2014; 34(5): 2581-2588, indexed in Pubmed: 24778080.

5. Pędziwiatr M, Natkaniec M, Kisialeuski M, et al. Adrenal incidentalomas: should we operate on small tumors in the era of laparoscopy? Int J Endocrinol. 2014; 2014: 658483, doi: 10.1155/2014/658483, indexed in Pubmed: 24817886

6. Panek W, Szydelko T, Lewandowski J, et al. Simultaneous laparoscopic adrenalectomy and laparoscopic nephron-sparing surgery - new experience with port placement. Videosurgery Miniinv. 2013; 8(4): 357-360, doi: $\underline{10.5114 / \text { wiitm.2011.35351 }}$

7. Fiszer P, Toutounchi S, Pogorzelski R, et al. Is tumor size a contraindication to laparoscopic adrenalectomy? Case report. Videosurgery Miniinv. 2012; 7(2): 144-146, doi: 10.5114/wiitm.2011.25931.

8. Donatini G, Caiazzo R, Do Cao C, et al. Long-term survival after adrenalectomy for stage I/II adrenocortical carcinoma (ACC): a retrospective comparative cohort study of laparoscopic versus open approach. Ann Surg Oncol. 2014; 21(1): 284-291, doi: 10.1245/s10434-013-3164-6, indexed in Pubmed: 24046101.

9. Hirayama T, Fujita T, Koguchi D, et al. Laparoscopic adrenalectomy for metastatic adrenal tumor. Asian J Endosc Surg. 2014; 7(1): 43-47, doi: 10.1111/ases.12076, indexed in Pubmed: 24251723.

10. Chen JYR, Ardestani A, Tavakkoli A. Laparoscopic adrenal metastasectomy: appropriate, safe, and feasible. Surg Endosc. 2014; 28(3): 816-820, doi: 10.1007/s00464-013-3274-z, indexed in Pubmed: 24337189.

11. Sastry P, Tocock A, Coonar AS. Adrenalectomy for isolated metastasis from operable non-small-cell lung cancer. Interact Cardiovasc Thorac Surg. 2014; 18(4): 495-497, doi: 10.1093/icvts/ivt526, indexed in Pubmed: 24357471.

12. Stransky P, Eret V, Urge T, et al. Laparoscopic Adrenalectomy for metachronous ipsilateral metastasis following nephrectomy for renal cell carcinoma. Videosurgery Miniinv. 2013; 8(3): 221-225, doi: 10.5114/ wiitm.2011.33813.

13. Pędziwiatr M, Matłok M, Kulawik J. At al. Laparoscopic adrenalectomy by the lateral transperitoneal approach in patients with a history of previous abdominal surgery. VideosurgeryMiniinv. 2013; 8(2): 146-51, doi: 10.5114/wiitm.2011.32942, indexed in Pubmed: 23853677.

14. Myśliwiec P, Marek-Safiejko M, Łukaszewicz J, et al. Videoscopic adrenalectomy - when does retroperitoneal seem better? WideosurgeryMiniinv. 2014; 9(2): 226-233, doi: 10.5114/wiitm.2014.41636, indexed in Pubmed: 25097691.

15. Dworakowska D, Drabarek A, Wenzel I, et al. Adrenocortical cancer (ACC) - literature overview and own experience. Endokrynol Pol. 2014; 65(6): 492-502, doi: 10.5603/EP.2014.0069, indexed in Pubmed: 25554619 .

16. Szydełko T, Lewandowski J, Panek W, et al. Laparoscopic adrenalectomy - ten-year experience. Cent European J Urol. 2012; 65(2): 71-74, doi: 10.5173/ceju.2012.02.art3, indexed in Pubmed: 24578932

17. Juszczak K, Drewa T. Adrenergic crisis due to pheochromocytoma - practical aspects. A short review. Cent European J Urol. 2014; 67(2): 153-155, doi: 10.5173/ceju.2014.02.art7 indexed in Pubmed: 25140229.

18. Toutounchi S, Pogorzelski R, Siński M, et al. A spontaneous paraganglioma-pheochromocytoma syndrome. Cent European J Urol. 2014; 66(4): 437-439, doi: 10.5173/ceju.2013.04.art12, indexed in Pubmed: 24757537.

19. Moreno P, de la Quintana Basarrate A, Musholt TJ, et al. Adrenalectomy for solid tumor metastases: results of a multicenter European study. Surgery. 2013; 154(6): 1215-22; discussion 1222, doi: 10.1016/i. surg.2013.06.021, indexed in Pubmed: 24238044. 